\title{
MANUNGGALING KALA DESA MELINTAS FENOMENA RUANG DAN WAKTU DALAM PENCIPTAAN SENI LUKIS
}

\author{
I Wayan Setem ${ }^{1}$
}

\begin{abstract}
Having observed and studied lingga-yoni, I have got an idea about "The Unity of Time-Space, Crossing the Phenomena of Time and Space in the Creation of Painting is the theme of my Works. What I would like to analyze here is the psychoanthropological aspects of lingga-yoni. Hopefully this analysis is viewed as an effort to reread reinterpret the symbol of linggayoni in my paintings. My perception of lingga-yoni related to the unity of time-space is not merely understood as a sensing quality but as a self projection of various values involving new interpretations. I can perceive the significance of lingga-yoni so that I am fully aware of its relationship with time and space. This perception is related not only to the cognitive achievement but also to the feelings of various values such as aesthetical, moral, and religious. Thus in this context, I place the creative exploration in the painting creation as a critical reflection crossing the time and space phenomena with the theme of "Manunggaling KalaDesa" (the unity of time-space).
\end{abstract}

Keyword: lingga-yoni, manunggal, kala desa, ruang, and waktu.

Berangkat dari pengamatan terhadap lingga-yoni dan setelah melakukan eksplorasi maka muncul gagasan tentang "Manunggaling Kala Desa, Melintas Fenomena Ruang dan Waktu dalam Penciptaan Seni Lukis”

${ }^{1}$ I Wayan Setemadalah Dosen Jurusan Seni Murni Fakultas Seni Rupa dan Desain Institut Seni Indonesia Denpasar. 
sebagai tema. Manunggaling kala desa berasal dari bahasa Sansekerta yang artinya waktu dan tempat/ruang (Zoetmulder, 1982: 440). Yang ingin dicermati ialah sudut-sudut psiko-antropologisnya dan telaahnya hendaknya dipandang sebagai upaya pembacaan kembali atas simbol lingga-yoni untuk ditawarkan pada seni lukis. Lebih jauh lagi berharap bahwa bacaan kembali ini akan dapat mengilhami reinterpretasi modern dari konsep-konsep lampau dan mendorong kreativitas lebih lanjut.

Bila ditinjau dari sudut antropologi, dengan bantuan konsep psikoanalitis Freudian, dapat diurai bahwa lingga-yoni merupakan simbol Tuhan yang dipercaya sebagai bapak dan ibu di alam semesta ini. Lingga adalah simbol Tuhan sebagai bapak, purusa, akasa, maskulin, ruang kosong (langit), dan yoni adalah simbol Tuhan sebagai ibu, pradana, feminin atau pertiwi (tanah) yang memberi kesuburan, kesejahteraan, kedamaian bagi semua kehidupan yang ada di alam. Kemanunggalan bapak dan ibu akan melahirkan kehidupan, dalam artian hubungan langit dan bumi (akasa dan pertiwi) menimbulkan ruang tempat kehidupan dan keseimbangan kosmos. Di sinilah lingga dan yoni merupakan kesatuan dinamis, seperti halnya pikiran dan hati yang saling melengkapi. Sulit dibayangkan bumi tanpa langit, ruang tanpa waktu. Pada wilayah ini pula lingga-yoni yang berwujud kelamin menjadi sangat sakral dan suci, sebagaimana adi kodrati-Nya.

Lingga-yoni adalah realitas fakta yang memberi spirit untuk direinterpretasikan terkait dengan "manunggaling kala desa, melintas fenomena ruang dan waktu". Di sinilah diperlukan pengetahuan yang berkesinambungan tentang lingga-yoni, seterusnya "diperas" hingga mendapatkan intisarinya.Hal ini tidak hanya berhadapan dengan lambang itu sendiri, tetapi dihadapkan pula kepada keseluruhan masyarakat yang mempercayainya sebagai kemanunggalan/kebersatuan, seperti api dan panasnya tidak terpisahkan, begitulah lingga-yoni adalah tunggal.

Kaitan lingga-yoni dengan ruang waktu karena persepsi tentang asal muasal kalender agraris Bali (Pawukon) terkait dengan mitos Watugunung yang menceritakan kisah inses seorang putra, Sang Watugunung sebagai refresentasi lingga, dengan ibunya, Sinta sebagai refresentasi yoni, serta bagaimana kedua pelaku ini dipisahkan secara simbolis oleh titik batas siklus kalender setelah Watugunung mendapat pencerahan para Dewata. Dengan adanya kalender maka muncul kesadaran akan ruang dan waktu yang sesungguhnya mengembalikan manusia kepada ajaran akan nilai kesejatian. 


\section{Manunggaling Kala Desa... (Wayan Setem)}

Perlu dijelaskan, dalam masyarakat Bali kesadaran kolektif tentang dunia dan alam semesta yang kosmocentris sangat menentukan gambaran mengenai ruang dan waktu yang dianggap sebagai daya kekuatan maha besar yang menguasai dan mengatur kehidupan penghuni semesta raya ini. Orang Bali percaya bahwa manusia berada di bawah pengaruh tenaga-tenaga yang bersumber dari pada penjuru mata angin, pada binatang-binatang dan planet-planet. Kekuatan ini dapat menghasilkan kemakmuran dan kesejahteraan, atau sebaliknya dapat menimbulkan kehancuran tergantung pada keberhasilan individu, masyarakat atau negara dalam menyelaraskan kehidupan dan kegiatannya dengan jagat raya. Keselarasan itu dapat ditempuh melalui petunjuk-petunjuk para ahli astrologi untuk menetapkan hari baik dan hari naas (hari buruk) yang mengacu pada penanggalan, wariga, tika dan pengider-ider.

Kepercayaan terhadap ruang dan waktu relatif yang bersifat dualistik (binary oposition), seperti sakral-profan, gunung-laut, siangmalam, absolut-riil, dan sebagainya. Namun dalam segala disharmoni pula kesejajaran dan kesederajatan antara 'lama' dan 'baru' pasti berlaku, meskipun dalam pertentangan. Melalui perkawinan kosmis kedua polarisasi ini diharmoniskan, direkonsiliasi dan disatukan. Konsepsi ini membawa makna dinamika, perjuangan, dan ikhtiar dalam menghadapi tantangan dalam kehidupan, sekaligus juga mengandung makna stabilitas.

Namun dalam era globalisasi, masyarakat mengalami benturan kebudayaan. "Tabrakan” waktu kapitalisme dengan waktu khas agraris Bali terjadi sangat dashyat serta selalu terjadi dualisme antara keinginan untuk mempertahankan tradisi dan menerima modernisasi sebagai tuntutan zaman. Seperti di permulaan tahun-tahun 1990-an ketika mahasiswa.Hal ini dirasakan tidak begitu kuasa berhadapan dengan investasi global, ruang dan waktu tidak lagi menjadi bagian utuh penduduk Bali. Pada waktu itu aktivitas pembangunan yang tidak terkontrol dan pesatnya perkembangan sektor pariwisata telah menyebabkan kerusakan lingkungan, penduduk luar datang membludak, sikap hedonis-materialistik berhadapan dengan nilai tradisi religius, dan ruang (mandala) sering dieksploitasi. Dengan demikian akan mengundang berbagai masalah di segala bidang sehingga merusak tatanan sakral-profan, hulu-teben, serta perubahan ruang dan waktu. 
Saya juga tergugah oleh permasalahan sosial, ekonomi, dan politik. Banyak pengalaman rohani dan pikiran saya di dalam persentuhan dengan persoalan kelestarian lingkungan, dan ekonomi yang absurd dipicu oleh industri pariwisata. Tetapi belum bisa dirumuskan pengalaman itu dengan baik di dalam alam kesadaran serta belum bisa menemukan bahasa visual yang cocok.

Baru setelah tahun 2007 pada saat studi di program pascasarjana Institut Seni Indonesia Yogyakarta barulah mulai bisa melihat lebih jernih pergeseran ruang dan waktu di Bali. Industri pariwisata yang di banggakan memang membawa keuntungan materialistis sangat besar bagi sebagian kalangan masyarakat Bali. Namun dampak negatif yang menjadi konsekuensi dari pergaulan dengan masyarakat luar berdampak pada perubahan-perubahan nilai luhur budaya lokal yang sudah mapan, lalu digantikan dengan budaya dan nilai-nilai luar yang dalam banyak hal tidak sesuai dengan nilai-nilai masyarakat Bali tradisional. Seperti diberitakan Kompas (31 Maret 2009), bahwa perkembangan industri pariwisata cendrung mengabaikan budaya dan merusak ekologi. Seperti ancaman keberadaan subak beserta ritualnya yang sangat terganggu. Gangguan itu berupa penggerusan lahan yang beralih fungsi menjadi hotel, homestay, lapangan golf dan akomodasi industri wisata lainnya. Masyarakat berharap pariwisata Bali kembali ke sumbernya (wisata budaya), yakni dengan elaborasi konsep pariwisata budaya yang bertumpu pada paradigma keserasian dan mengaitkan secara fungsionalinteraktif antara komponen kebudayaan, pariwisata dan lingkungan.

Renungan masalah ruang dan waktu seperti paparan di atas menarik dicermati kembali terutama di dalam dimensinya yang suci atau keramat agar dapat menangkap maknanya sehingga meminimalisasikan tabrakan ideologi. Selanjutnya akan terbuka ruang untuk hibriditas dan dimensi transnasional yang lebih dinamis. Dengan manunggaling kala desa akan terwujud "kesadaran eksis" (di sini dan saat ini).

Pada konteks itulah, mulzi menempatkan eksplorasi kreatif penciptaan karya seni lukis sebagai upaya refleksi kritis melintas fenomena ruang (desa) dan waktu (kala) dengan tajuk "manunggaling kala desa”. Manunggal secara tehnis melukis juga berarti menggabungkan unsur-unsur/elemen-elemen seni rupa, media serta tehnik-tehnik yang beragam menjadi satu kesatuan yang harmoni. Dari adanya gagasan relasi seperti itulah, maka karya seni lukis yang saya ciptakan menjadi sangat terbuka bagi kemungkinan kreatif. 


\section{KONSEP PENCIPTAAN}

\section{Pengertian Seni Lukis}

Seni lukis ialah penyusunan kembali konsep dan emosi dalam suatu bentuk baru yang merupakan wujud seni dwimatra. Pengertian seni lukis yang dipelajari terbatas pada wujud seni rupa dua dimensional untuk membatasi agar tidak meluas jangkauannya. Sebagai medium ekspresi seorang seniman, seni lukis bertujuan menyenangkan dirinya sendiri dan diri orang lain. Dengan demikian mengandung nilai komunikasi untuk menyatakan pikiran dan perasaan pelukisnya kepada pemirsa. Unsur-unsur seni lukis merupakan hal yang penting bagi seniman dalam mengekspresikannya seperti garis, warna, ruang, dan tekstur dalam suatu susunan ritmis, kontras, seimbang yang ditawarkan kepada pemirsa sebagai gejala bahasa rupa.

Secara teknik, lukisan merupakan seni penerapan warna pada permukaan yang datar (kanvas, panel, tembok, kertas dan sebagainya) untuk menghasilkan ilusi tentang ruang, gerak, susunanan dan bentuk yang dihasilkan oleh kombinasi unsur-unsur tersebut. Diketahui pula bahwa melalui rencana-rencana teknis diekspresikan intelektual, emosi, simbol, dan nilai lainya yang bersifat subyektif.

Dengan demikian, untuk mewujudkan sebuah lukisan ada dua faktor penting yakni, faktor ideoplastis dan fisikoplastis. Faktor ideoplastis berupa ide atau pengalaman emosi dan fantasi. Sedangkan faktor fisikoplastis berupa unsur-unsur visual atau elemen-elemen seni rupa yang dapat memberikan berbagai kesan serta simbol dalam penerapannya. Oleh karena itu seni lukis adalah transformasi dari endapan-endapan pengalaman estetis untuk menyatakan kebenarankebenaran batin yang tidak dapat diungkapkan melalui kata-kata.

\section{Manunggal}

\section{1). Kemanunggalan Kala Desa}

Dalam Kamus Jawa Kuna Indonesia, kala desa (Sansekerta) artinya: "waktu dan tempat", saat yang tepat, kesempatan yang baik. Lebih jauh, kala artinya: bagian waktu, tertentu. Waktu sebagai takdir yang tidak dapat dielakkan, Kala sebagai dewa maut dan penghancur. Manakala, pinakala artinya mempunyai waktu tertentu atau periode. Tanpakala artinya (tanpa waktu atau periode tertentu) tetap, terus 
menerus. Sedangkan desa berasal dari bahasa Sansekerta yang artinya: (a) daerah, wilayah, tempat, bagian, propinsi, (b) perdesaan (sebagai lawan kota), daerah pedalaman, daerah luar kota, perdusunan: desa dusun, kampung (Zoetmulder, 1982: 440 dan 212). Dalam hal ini “desa” dapat diartikan sebagai tempat atau ruang.

Sumarjo (2002: 85) dalam Arkeologi Budaya Bangsa menyebutkan pemikiran tentang ruang: (a) pandangan subjektif tentang ruang adalah konsep subjektif saja, tanpa realitas. Dengan kata lain, tanpa dasar objektif, karena itu hanya bentuk subjektif dalam persepsi; (b) pandangan positifisme, berpendapat bahwa ruang dan waktu tidak mempunyai arti. Alasannya, keduanya bukan realitas empiris yang dapat dibuktikan dengan metode-metode empiris ilmiah; (c) pandangan realistis-ekstrim mengatakan bahwa ruang itu tidak terbatas, abadi, tidak terobservasi dan menjadi syarat kemungkinan ekstensi. Ruang terbagi dua, yakni ruang yang memuat dunia serta ruang yang kosong di seberang; dan (d) pandangan ke empat mengatakan bahwa ruang adalah riil sejauh terdapat keluasan berdemensi dengan panjang, lebar dan tinggi.

Ruang dan waktu bagi saya di dalam realitas memang tidak ada sekaligus ada. Dengan menyebut apa yang terlihat sebagai ruang, kita yakin sedang menggambarkan sesuatu tempat yang nyata dan dapat dikenali. Ketika melihat ruang, kita terbawa untuk memikirkan tekateki ruang sebagai suatu tempat keramat dan suci, khususnya di Bali, berhubungan erat dengan kepercayaan dan ritus-ritus. Di situ orang mencari dan menyerap ruang dengan menyatu dari ujung dunia ke ujung yang lainnya.

Menurut Bakker (1995: 165-166), ruang ialah kolegialitas substansi-substansi kosmis yang berelasi dimensional-intensif. Tetapi ruang tidak pernah ditemukan secara umum, atau seakan dari suatu titik pandangan yang di luar dunia, melainkan senantiasa berada dalam perspektif salah satu substansi. Hakikat dari tempat dan ruang itu adalah kenyataan yang satu, yakni semua pengkosmos diambil bersama dalam relasi kuantitatif-intensif, tetapi selalu menurut perspektif dari pihak substansi individual.

Manusia memiliki tempat dan ruang paling jelas dan dapat mengarahkan perhatiannya ke lingkaran luas dan jauh, atau dapat juga 
memusatkannya pada suatu sentrum dekat, dapat tergeser dari lingkaran yang dekat ke lingkungan yang luas dan universal. Artinya, bahwa manusia tidak terpenjara dalam lingkungan terbatas.

Sedangkan waktu adalah suatu tatanan di luar hal manusia dan peristiwa. Ada satu waktu asali dan primordial (mitis), dan semua peristiwa berakar dalam waktu asali itu, dan mendapat identitas serta mutunya dari sana. Dengan demikian mereka mendapat kekokohan besar. Itu terutama berlaku bagi peristiwa-peristiwa sentral dalam hidup manusia seperti kelahiran, kematian, inisiasi, pernikahan, tetapi juga bagi pengalaman alam seperti banjir, dan gempa bumi. Maka peristiwa alami dikuasai oleh takdir; dan semua peristiwa manusiawi harus menyesuaikan diri dengan keteraturan yang telah ditetapkan (Bakker, 1995: 113).

Perhatian terhadap kejadian-kejadian primodial yang berhubungan dengan penciptaan atau kelahiran manusia dirasakan sebagai kenyataan utama dari kehidup-an dunia, oleh karena itu terus diulangi dalam bentuk upacara. Ini berarti waktu yang disucikan diwariskan dari generasi ke generasi selanjutnya.

Untuk memperhitungkan titik waktu atau saat yang baik atau kurang baik, dipakai tabel-tabel (tika) yang membagikan hari dan malam dalam bagian-bagian, biasanya dalam lima atau tujuh titik (kotika lima atau tujuh) setiap titik waktu atau saat diidentifikasikan dengan salah satu dewa atau dewi, hewan, planet atau katagori lain. Diperhitungkan juga 30 hari dalam satu bulan, dan 12 bulan pertahun. Perhitungan waktu itu berdasarkan perhitungan mengikuti pusingan bumi pada sumbunya. Karena gerakan berputar bumi pada sumbunya searah dengan jarum jam maka setiap saat akan terjadi perubahan waktu. Satu kali bumi berputar pada sumbunya disebut satu hari yang lamanya 24 jam.

Ruang yang dimaksud dari penciptaan ini, adalah upaya untuk membentuk gambaran atau konsep-konsep virtual yang secara tidak langsung didapat dari sensasi-sensasi penginderaan atau fenomena. Sedangkan ruang dalam imaji rupa bukan sekedar latar, lokasi ataupun tempat dan waktu terjadinya peristiwa penginderaan. Ruang disini merupakan konsep virtual yang tidak terjelaskan dan tidak terpahami secara nyata, sebagai upaya imajinasi imajiner dari permainan ilusi.

Jika bidang gambar (kanvas) adalah ruang, maka di tempat itulah sesungguhnya terbuka kesempatan untuk memainkan gagasan, imajinasi, 
termasuk dalam mengelola setiap unsur atau elemen untuk mendapatkan berbagai kemungkinan bahasa visual.

\section{2). Kemanunggalan Lingga-Yoni}

Di Indonesia, pemujaan terhadap lingga-yoni berkembang sangat luas yang terbukti dengan ditemukannya lingga-yoni di berbagai bangunan suci candi maupun pura terutama di Bali. Sebagai contoh di Pura Pusering Jagat yang terletak di Desa Pejeng, Gianyar, Bali. Nampak bahwa lingga-yoni tersebut berbentuk batu me-manjang dengan ukuran $97 \mathrm{~cm}$ dan keliling penampang $132 \mathrm{~cm}$ berdampingan dengan yoni. Selain itu, lingga-yoni terdapat pula di Pura Tirta Empul Tampak Siring. Bentuk lingga itu memanjang berdiri, sementara yoni berbentuk segi empat yang berlubang di tengahnya berisikan air. Yoni tersebut diyakini sebagai tempat mengalirnya air suci, sehingga di Pura Tirta Empul digunakan sebagai tempat untuk melukat.

Kata lingga berasal dari bahasa Sansekerta, di samping arti yang lainnya, lingga berarti "tanda padanan phallus kemaluan laki-laki”. Di dalam buku Iconography Dictionary of the India Religion HinduismBuddhism-Jainism diuraikan bahwa lingga (linggam) berarti simbol atau lambang jenis kelamin laki-laki. Di India Selatan dan Tengah (Madya Pradesh), pemujaan lingga sangat populer dan bahkan ada suatu sekte khusus memuja lingga yang menamakan dirinya sekte Linggayat. Pada umumnya mereka memakai kalung dengan hiasan beberapa buah lingga sama halnya orang Nasrani memakai kalung dengan salibnya (Ambarawati, 1997: 52).

Penyembahan kepada Tuhan dan leluhur direalisasikan ke dalam bentuk lingga-yoni merupakan sebuah simbol yang paling halus dan paling rumit dalam kasanah budaya Bali dan Jawa karena terkait dengan seks. Ini terjadi karena per-soalan seks bagi masyarakat dianggap sebagai masalah yang tabu untuk dibicarakan secara terbuka. Maka dari itu seksualitas sering kali ditampilkan sehalus mungkin, secara tidak langsung atau tersirat. Di sisi lain, persoalan seksual selain sebagai persoalan mistik (relegi) dan kesaktian (laku) juga merupakan persoalan yang sebenarnya paling banyak dibicarakan dalam cerita-cerita tradisional dan babad.

Lingga secara langsung, tentu saja kata itu menunjuk kepada penisnya Siwa —yang “agung dan tanpa akhir” (Greertz, 2000: 200). Kata itu juga menunjuk kepada pewujudan penis yang dibuat 
dalam bentuk kasarnya- batu-batu berbentuk persegi panjang dan dibulatkan di sebelah atas. Selain itu masih banyak lagi yang dimaknai sebagai lingga seperti, jalinan daun untuk me-mercikkan tirta (air suci), meru, bade (menara kremasi), keris, renunganrenungan api, permata yang terdapat di kening pendeta dan gununggunung berapi. Sedangkan yoni, secara langsung menunjuk kepada vagina; istri Siwa sebagai sakti-nya.

Sebagai simbol Siwa, lingga merupakan aspek sekunder dari lambang kelaki-lakian yang baru akan menimbulkan tenaga atau energi setelah bersatu dengan Parwati, sakti Siwa dilambangkan dengan yoni, lambang kewanitaan.

Konsep lingga-yoni menggambarkan keseimbangan hidup dalam demensi dualistis, yaitu keyakinan adanya keharmonisan serba dualistis. Implementasi dari konsep ini secara ritual dapat kita jumpai dalam upacara keagamaan seperti dalam bentuk jajan suci rahina wengi, Ardhanareswari, Smara-Ratih serta hitam putih. Sebagai ungkapan rasa syukur dan terima kasih kepada Sang Pencipta. Dua unsur yang berbeda antara purusa-pradana, laki-perempuan, penis-vagina, bumi-langit, tinggi-rendah, abssolut-relatif, hidup-mati, kosmos-chaos, makna-gejala, tunggal-aneka, impoten-poten, abstrak-konkrit, azas-maya, kiwa-tengen.

\section{Konsep Pewujudan/Penggarapan}

Wujud karya yang saya ciptakan memiliki kecendrungan abstrak figuratif supaya bisa menyelipkan/menampilkan unsur-unsur simbolisme

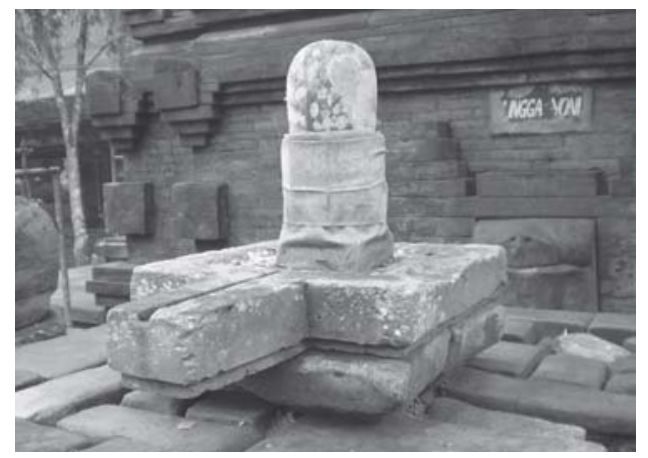

Gambar 1. Lingga-Yoni di Pura Tirta Empul, Tampak Siring, Gianyar. 
Hindu-Bali. Hal ini juga dengan sengaja menempatkan sistem rupa di ambang abstrak figurasi simbolis untuk "berbicara" tentang ruang dan waktu. Alasan pemilihan abstrak figuratif dalam penciptaan ini supaya lebih leluasa menuangkan gagasan dengan hanya mengambil intisari dari tema maupun subjek kala desa (ruang waktu) yang saya pilih untuk ditampilkan dalam seni lukis.

Kata abstrak mengandung arti tidak berwujud, tidak berbentuk, mujarad, niskala. Soedarso Sp. (1998: 79) berpendapat, bahwa gaya, corak atau langgam ataupun style, adalah sebenarnya berurusan dengan bentuk luar sesuatu karya seni. Sedangkan aliran, faham atau isme lebih menyangkut pandangan atau prinsip yang lebih dalam sifatnya. Lebih lanjut Soedarso Sp. (2000: 123) menjelaskan mengenai seni abstrak adalah:

Dalam pengertian yang paling murni abstrak adalah ciptaanciptaan yang terdiri dari susunan garis, bentuk dan warna yang sama sekali terbatas dari ilusi atas bentuk-bentuk di alam. Namun secara lebih umum, ialah seni di mana bentuk-bentuk alam itu (kalau ada) tidak lagi berfungsi sebagai objek ataupun tema yang harus dibawakan, melainkan tinggal sekedar sebagai motif saja, sebagai dalih untuk membuat sesuatu...dari pada tidak berbuat apa-apa.

Mengekspresikan suara bathin merupakan salah satu ciri khas abstraksionisme. Seni merupakan suatu kemujaran yang mesti datangnya dari dalam dan bukan meniru alam. Bentuk yang mesti diciptakan adalah bentuk-bentuk yang baru, dalam artian, lain dari bentuk yang kasat mata (Karja, 1996: 45).

Keberadaan seni abstrak di Bali dalam kaitan pengertian makna abstrak yang lebih luas, maka seni prasejarah dengan transformasi bentuk-bentuk yang ada dapat digolongkan seni abstrak. Dengan demikian di Bali sudah ada seni abstrak figuratif sejak berabad-abad. Namun seni abstrak sebagai bentuk aliran dalam perkembangan seni lukis Bali modern, memang baru dikenal sejak adanya pendidikan seni rupa formal.

Seni lukis abstrak figuratif adalah karya seni lukis yang penciptaannya bertolak dari gejala objektif. Seni abstrak figuratif merupakan proses pengolahan bentuk secara deformasi, dari bentuk- 
bentuk merefresentasikan alam hingga bentuk-bentuk yang ada. Dengan demikian akan kita jumpai hasil-hasil deformasi visual dari yang dekat hingga sangat jauh, tergantung pada eksperimen dan pengalaman seniman bersangkutan.

Maka dalam mentransformasikan pengalaman batin ke dalam bentuk karya visual, merupakan suatu pencitraan terhadap nilai-nilai kehidupan yang dipandang sebagai dunia makna yang bernuansa simbolik sebagai suatu cara ungkap dari ide-ide bersifat personal. Ide terbentuk dari impresi-impresi, dan pengalaman-pengalaman rasa batin.

Berkaitan dengan pengertian corak dan aliran tersebut, maka bagi saya dalam menciptakan karya seni lukis, abstrak adalah sebagai corak, dalam arti lebih berkaitan dengan aspek fisiknya. Abstrak figuratif membangun imaji dari garis dan warna yang ekspresif. Dari eksplorasi warna dan nuansanya seringkali tidak dapat dihindari ada jejak-jejak realitas yang "tertinggal” seperti berbagai benda-benda organis yang ditemui di alam yang kita pahami selama ini. Di dalamnya ia membangun "sesuatu", atau memberi ruang yang sangat lapang bagi pengembaraan imajinasi.

\section{METODE/PROSES PENCIPTAAN}

\section{Metode Penciptaan}

Metode penciptaan yang digunakan dalam penciptaan ini mengacu pada pendapat Hawkins, dalam bukunya yang berjudul Creating Trought Dance, (dalam Soedarsono, 2001: 207). Hawkins menandaskan bahwa penciptaan sebuah karya tari yang baik selalu melewati tiga tahap yakni: pertama, exploration (eksplorasi); kedua, improvisation (improvisasi); dan ketiga, forming (pembentukan atau komposisi). Ketiga tahap tersebut ditinjau dari prinsip kerjanya sebenarnya dapat pula diterapkan dalam proses penciptaan karya seni lukis.

Lebih lanjut Soedarsono berpendapat bahwa, karena ada perbedaan yang hakiki antara seni pertunjukan dengan seni rupa, rumusan dari Hawkins perlu sedikit dimodifikasi agar bisa dipergunakan untuk seni rupa. Kegiatan improvisasi untuk tari perlu diganti dengan kegiatan eksperimentasi untuk seni rupa. Pergantian ini, walaupun namanya berbeda, tetapi sebenarnya arah kerjanya sama. Dalam penciptaan karya seni lukis, aktivitas eksperimentasi dilakukan melalui 
percobaan-percobaan dalam bentuk sketsa untuk mendapatkan rancangan yang diinginkan.

\section{Tahap-Tahap Penciptaan}

1. Eksplorasi

Tahap eksplorasi mencakup pula berbagai upaya penjajagan atau berbagai sudut pandang dan cara penggarapan serta bentuk-bentuk yang mau dibangaun. Disinilah mulai dicari berbagai kemungkinankemungkinan dalam konsep, bentuk dan presentasinya. Metode brainstrorming dan berpikir lateral dapat diterapkan di sini. Dalam eksplorasi sangat dituntut berpikir secara lateral dan divergen (perhatian menyebar keberbagai arah yang mungkin dilakukan).

Melalui brainstorming akan dapat membangkitkan ide-ide yang menerobos, ide-ide yang punya potensi untuk "mengkawinkan” hal-hal tadinya nampak tidak berkaitan sama sekali. Dengan metode ini suatu permasalahan dapat terlihat seperti ruang yang mengandung banyak kantong virtual berisi alternatif-alternatif untuk pemecahan masalah dalam seni lukis.

Berpikir lateral yang bersifat divergen menekankan berbagai pendekatan dan cara pandang berbeda untuk melengkapi cara berpikir vertikal yang konvergen. Dalam seni lukis diaplikasikan untuk mengatasi kebekuan pola pandang, mem-bangkitkan persefsi-persefsi alternatif, mendekonstruksi habitat lama yang acap kali tidak lagi relevan, dan mampu melihat permasalahan dari berbagai sudut pandang secara dinamis. Kedinamisan itu seperti air yang terus bergerak mengikuti wadag dan lingkungan dimana ia berada, guna menangkap gambarangambaran yang tadinya samar-samar untuk diwujudkan menjadi karya (Marianto, 2006: 3).

Pada dasarnya tahap-tahap penciptaan berakar dari serangkaian pengamatan yang mendalam terhadap lingga-yoni di pura dan candicandi. Kemudian dilakukan studi kepustakaan menyangkut norma-norma adat dan agama dalam penataan kehidupan di lingkungan masyarakat Bali. Untuk melengkapi data-data berkaitan dengan penciptaan ini juga diadakan penelusuran tentang esensi lingga-yoni, ruang dan waktu melalui kajian pustaka dan wawancara sehingga melahirkan interpretasi intersubjektif sebagai manunggaling kala desa. 
Eksplorasi terhadap lingga-yoni dengan berkunjung ke berbagai tinggalan arkeologi seperti Pura Pusering Jagat, Pura Kebo Edan, Pura Melanting, Pura Tampaksiring, Balai Pelestarian Purbakala Bali di Gianyar Bali; Pura Batu Madeg, Pura Candidasa di Karangasem Bali; Candi Sukuh, Candi Prambanan dan yang lainya. Selain lingga-yoni yang memiliki konsep kemanunggalan juga ada arca Ardhanareswari sebagai lambang dwi tunggal, berupa kesatuan Siwa dan sakti-nya Dewi Parwati. Arca Ardhanareswari terdapat di Pura Puseh Tejakula Buleleng dan Pura Melanting Pejeng Gianyar.

Dari eksplorasi konsepsi diperoleh intisari dari berbagai gagasan yang merupakan kekuatan dan substasi yang akan dipresentasikan. Di samping eksplorasi konsepsi juga dilakukan eksplorasi analisis visual, media, teknik, dan estetik.

\section{Eksperimen}

Berbagai eksprimen penerapan teknik pencapaian artistik dengan berbagai medium untuk mengoptimalkan berbagai proses perlakuan terhadap media melalui pendekatan teknik konvensional dan nonkonvensional. Pemilihan media dengan mencoba menggali berbagai kemungkinan media seperti: (a) modeling paste produksi Royal Talens Apeldoorn Holland; (b) cat akrilik merk Amsterdam produksi Royal Talens Apeldoorn Holland; (c) cat akrilik merk Lukascryl Studio produksi Dr. Fr. Schoenfeld GmbH \& CO Germany; (d) akrilik merk Galeria produksi Winsor Newton, London (England); (5) akrilik merk Star produksi Maimeri SPA, Italy; dan (e) mowilex water-based produksi CV Mowilex Jakarta.

Bersamaan eksperimen penerapan teknik pencapaian artistik juga dilakukan eksperimen visual dengan membuat sketsa-sketsa menggunakan pensil EE, tinta cina, cat air, kolase pada kertas A4s (21,5 x 29,7 cm). Dalam membuat sketsa itu terkadang dikombinasikan dengan berbagai teknik seperti meresponnya dengan kolase gambar-gambar dari koran dan majalah, sablon sederhana serta melobangi dengan dupa yang telah dinyalakan untuk mendapat efek artistik. 


\section{Pembentukan}

Tahap pembentukan merupakan pewujudan dan penggalian berbagai aspek visual artistik dan penajaman estetika dengan kemampuan teknis maupun analisis intuitif. Dalam pembentukan, digali dan dimanfaatkan nilai-nilai probabilitas dari berbagai aspek dan yang terkait dengan visual maupun teknik artistik lainnya serta representasi konsep estetikanya. Dengan menggali dan membuka berbagai kemungkinan akan mampu memunculkan gagasan, imajinasi dan berbagai pencitraan yang bersifat simbolik dan metaforik dalam kerangka untuk melahirkan jati diri/keunikan.

Karena dalam proses kreatif melibatkan imajinasi, maka tidak menutup kemungkinan untuk mengadakan improvisasi-improvisasi dalam bentuk, komposisi dan pewarnaan sesuai suasana batin saat itu. Dalam tahap ini mencoba-coba mencari berbagai kemungkinan dari ideide dan konsep-konsep yang telah dinyatakan dalam tahap eksplorasi. Tahap ini penting sekali dilalui kembali demi penyegaran serta aktualisasi kerja kreativitas. Dari proses kerja improvisasi ini, hal-hal yang terwujud tanpa sengaja dengan nilai artistik tinggi terus dikembangkan dengan merespon secara kontiyu sehingga mampu melahirkan citra-citra (bentuk) yang dikehendaki. Selanjutnya blok-blok warna yang dirasakan menggangu direspon lagi yang agar terwujud karya yang harmoni.

Dalam melukis menggunakan pedoman pada persepsi batin hasil dari pengelihatan mata yang mengarah pada refresentasi dari konsep manunggaling kala desa. Cara kerja kreatif yang dilakoni seperti "musafir" bergerak menjelajahi berbagai kemungkinan-kemungkinan sehingga membuka ruang-ruang imajiner yang berpotensi untuk melahirkan citra-citra dengan kemungkinan yang tidak terbatas pula. Dalam konteks kerja tersebut senantiasa memperbaharui pola pandang, dan berani melihat permasalahan dari berbagai perspektif, serta memandangnya "dari luar dan sekaligus dari dalam”.

Karya Lingga di Pusaran Bumi, dan Lingga Menembus Yoni merupakan hasil dari renungan misteri kemanunggalan dualisme priawanita dipahami sebagai sari rasa tunggal atau sarira satunggal. Dengan demikian maka setiap orang asalkan benar dalam menerapkan persenggamaan, saat menanamkan jiwa dalam rahim istri tercinta dengan bukan atas kobaran nafsu birahi saja, tentu akan dikaruniai keturunan berkualitas (bibit unggul yang memiliki jiwa luhur). Namun jika terjadi 
penyalahgunaan seks, dimana sejak semula terjadi "kama salah" tetes, bisa terlahir "lost generation”, bagaikan Bathara Kala yang bersifat angkara murka, merusak harmoni kehidupan dunia.

Seks bukan sekerdar menyalurkan hasrat birahi antara lelaki dan perempuan, namun merupakan perpaduan dua hati yang saling mencinta. Tujuan perkawinan bukan semata-mata untuk mencari kenikmatan hubungan seksual, tetapi perasaan manunggalnya suamiistri pada saat puncak orgasme bersama, yang menjadi peng-ikat utama dalam mencapai perasaan senyawa-setubuh. Kesatuan rasa ini ibarat "curiga manjing warangka, warangka majing curiga".

Menurut teori "Cosmic Mariage" atau perkawinan kosmis dikemukakan bahwa, semua yang ada timbul dari hubungan kelamin. Bahkan, seluruh dunia diciptakan oleh persetubuhan antara dewa pencipta dengan sakti-nya. Masyarakat Bali yang dapat dikatagorikan sebagai masyarakat primordial sawah (Sumardjo, 2002: 74), lebih berorientasi pada kesuburan dan kesejahteraan sehingga bentuk-bentuk ritual kesejahteraan dan kesuburan dilakukan. Begitu juga berbagai bentuk arca feminin yang memperlihatkan payudara dan pinggul wanita yang besar memberikan petunjuk bahwa kesuburn merupakan hal yang sangat dibutuhkan. Meskipun aspek feminin (dewi) lebih ditonjolkan dalam pemujaan untuk mendapatkan kesuburan, namun keberadaannya tidak dapat dilepaskan dari aspek maskulin (dewa) karena keduanya adalah satu kesatuan yang tidak dapat dipisahkan.

Hakikat yang paling penting dari karya ini memberi penyadaran bahwa dalam melakukan senggama jangan hanya bersifat kenafsuan belaka atau kebirahian, tetapi berlandaskan proses dan hasil dari hubungan tersebut hendaknya benar, suci, indah. (Lihat Gambar 3. dan 4.). 
MUDRA VOLUME 24 NO.1 JANUARI 2009

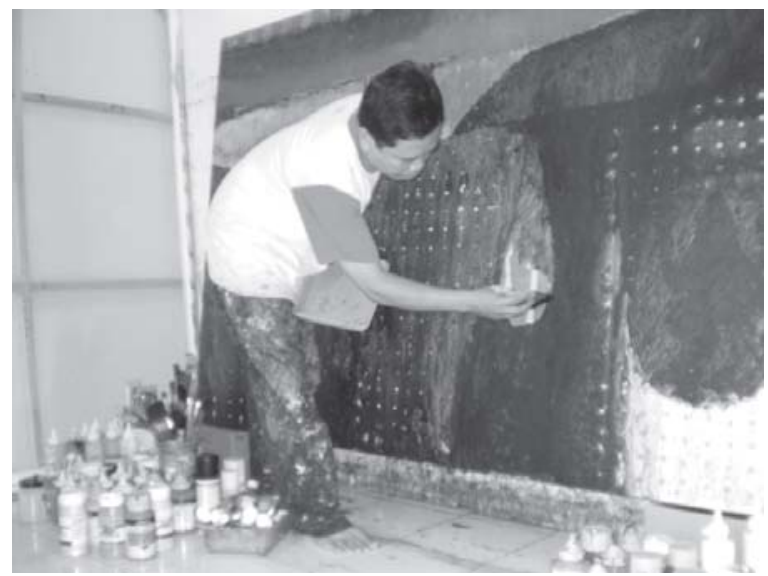

Gambar. 2. Proses

melukis membuat

bentuk-bentuk detail.

Gambar. 3.

Lingga di Pusaran

Bumi, 2009, akrilik

pada kanvas,

$160 \times 200 \mathrm{~cm}$.
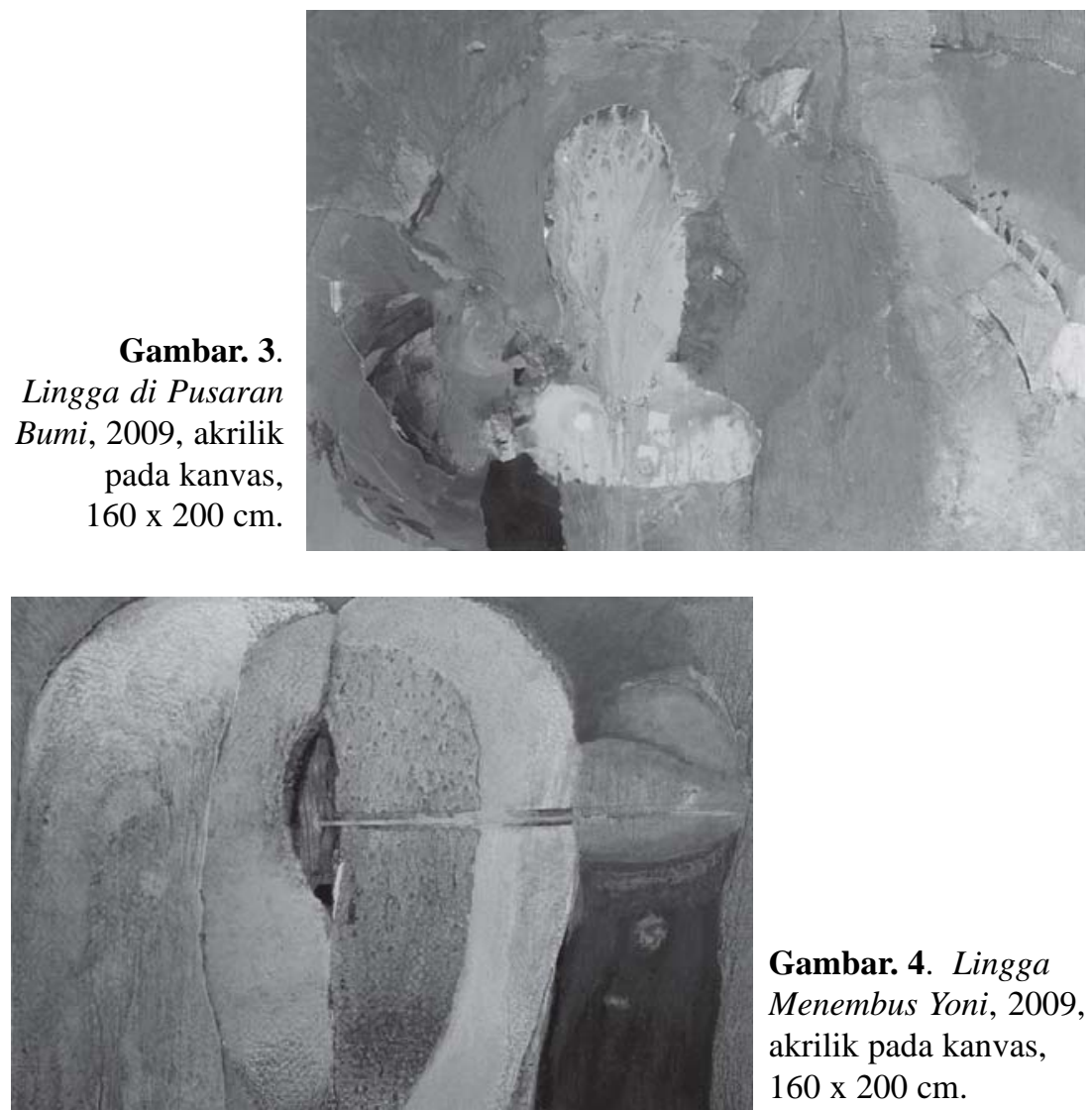

Gambar. 4. Lingga

Menembus Yoni, 2009, akrilik pada kanvas, $160 \times 200 \mathrm{~cm}$. 
Manunggaling Kala Desa... (Wayan Setem)

\section{SIMPULAN}

Penciptaan karya "Manunggaling Kala Desa, Melintas Fenomena Ruang dan Waktu dalam Penciptaan Seni Lukis", pada dasarnya merupakan pewujudan atau presentasi ekspresi pribadi yang bersifat subjektif. Hal tersebut sangat wajar karena menterjemahkan perasaan dan emosi ke dalam bentuk bahasa visual yang ditunjang oleh pengalaman penggunaan media dan teknik.

Dalam berkarya selalu mengonsentrasikan diri terhadap orisinalitas atau kebaruan semata, tetapi setia pada hati nurani serta kesadaran estetik. Dengan mendapat pertolongan yang bermanfaat dari tradisi berupa unsur-unsur simbolis Hindu-Bali yakni, lingga-yoni, mandala, rwa bhineda, trihita karana, dan lain sebagainya maka terciptalah karya-karya yang memiliki keunikan dalam tekstur, komposisi, warna, detail dan citra bentuk. Begitu juga munculnya berbagai kemungkinan teknik yang saya anggap baru, seperti penerapan warna semi trasparan dengan cara dilelehkan maka terjadi efek pecah sebagai tekstur yang sangat artistik.

Karena adanya proses improvisasi, maka hasil akhir yang terwujud berupa karya yang secara visual termasuk abstrak figuratif. Adapun visualisasinya diwujudkan dengan memanfaatkan elemenelemen visual seni rupa beserta prinsip-prinsip penyusunannya. Pada tataran visual nampak sistem rupa di ambang figurasi simbolis dan abstraksi murni supaya dapat dengan leluasa "berbicara" tentang ruang dan waktu. Konsekuensinya pada karya-karya adalah "kelonggaran" bentuk atau "pelapisan” visual yang kadang kala menimbulkan kejutankejutan dan menimbulkan berbagai macam imajinasi bagi yang mengamati.

Dalam eksplorasi yang mencakup pula berbagai upaya penjajagan, terkadang pengalaman-pengalaman unik terjadi, artinya dalam mendatangi tinggalan-tinggalan arkeologi maupun situs-situs linggayoni di suatu pura atau candi saya memiliki pengalaman transenden, merasakan vibrasi suasana magis. Kondisi seperti itu seakan merefleksikan jalan spiritual menuju esensi hidup. 


\section{DAFTAR RUJUKAN}

Ambarawati, Ayu. 1997, "Lingga-Yoni di Pura Puseh Babakan Kecamatan Penebel Kabupaten Tabanan”, dalam Forum Arkeologi, No. II Oktober 2007, Balai Akeologi, Denpasar.

Bakker, Anton.1995, Kosmologi dan Ekologi: Filsafat tentang Kosmos

Sebagai Rumah Tangga Manusia, Kanisius, Yogyakarta.

Ben/Ays/Ans/ Hrd, (31 Maret 2009), "Industri Pariwisata Bali;

Perkembangan Wisata Usik Tradisi”, Kompas.

Geertz, Clifford. 2000, Negara Teater: Kerajaan-Kerajaan di Bali Abad Ke-sembilan Belas, Yayasan Bentang Budaya, Yogyakarta.

Karja, I Wayan, (Juni 1996), “Abstraksionisme dalam Seni Lukis”, dalam Wreta Cita No. 6, Sekolah Tinggi Seni Indonesia Denpasar, Denpasar.

Marianto, M. Dwi. 2006, “Metode Penciptaan Seni”, dalam Jurnal Surya Seni, Vol. 2 No. 1 September 2006, Program Pascasarjana Institut Seni Indonesia Yogya-karta, Yogyakarta.

Soedarso Sp. 1998, Trilogi Seni dan Keindahan; Penciptaan Eksistensi dan Kegunaan, Institut Seni Indonesia Yogyakarta, Yogyakarta.

Soedarsono, RM. 2001, Metodologi Penelitian Seni Pertunjukan dan

Seni Rupa, Masyarakat Seni Pertunjukan Indonesia (MSPI), Bandung.

Sumardjo, Jakob.2002, Arkeologi Budaya Indonesia (Pelacakan Hermeneutis-Historis Terhadap Artepak-artepak Kebudayaan), Qalam, Yogyakarta.

Zoetmulder, P.J.1982, “ kala desa”; "manakala”; “pinakala”; “tanpakala”, Old Javanese-English Dictionary, s'gravenhageMartinus Nijhoff: Leiden. 